\title{
A role for surface lymphotoxin in experimental autoimmune encephalomyelitis independent of LIGHT
}

\author{
Jennifer L. Gommerman, ${ }^{1}$ Keith Giza, ${ }^{2}$ Stuart Perper, ${ }^{2}$ Irene Sizing, ${ }^{1}$ Apinya Ngam-ek, ${ }^{1}$ \\ Cheryl Nickerson-Nutter, ${ }^{2}$ and Jeffrey L. Browning ${ }^{1}$
}

${ }^{1}$ Department of Exploratory Sciences, and

${ }^{2}$ Department of Pharmacology, Biogen Inc., Cambridge, Massachusetts, USA

\begin{abstract}
In studies using genetically deficient mice, a role for the lymphotoxin (LT) system in the pathogenesis of experimental autoimmune encephalomyelitis (EAE) has remained controversial. Here, we have reassessed this conclusion by using a fusion protein decoy that blocks the LT pathway in vivo without evoking the developmental defects inherent in LT-deficient mice. We have found that inhibition of the LT pathway prevented disease in two models of EAE that do not rely on the administration of pertussis toxin. Surprisingly, disease attenuation was due to specific blockade of $L T \alpha \beta$ binding rather than the binding of LIGHT to its receptors. In a third system that requires pertussis toxin, LT inhibition did not affect disease, as was observed when the same model was used with LT-deficient mice. Disease prevention in pertussis toxin-free models was associated with defects in $T$ cell responses and migration. When the DO11.10 T cell transgenic system was used, inhibition of the LT pathway was shown to uncouple $\mathrm{T}$ cell priming from $\mathrm{T}$ cell recall responses. Therefore, it is hypothesized that the LT pathway and its ability to maintain lymphoid microenvironments is critical for sustaining late-phase $\mathrm{T}$ cell responses in multiple sclerosis.
\end{abstract}

J. Clin. Invest. 112:755-767 (2003). doi:10.1172/JCI200318648.

\section{Introduction}

Experimental autoimmune encephalomyelitis (EAE) has been induced in lymphotoxin- $\alpha$-deficient $\left(L T \alpha^{-/}\right)$, $L T \beta^{--}, T N F^{-/-}$, and $T N F / L T \alpha^{-/}$mice to dissect the relative contributions of the LT and TNF pathways to multiple sclerosis, often with conflicting results (1-6) (reviewed in ref. 7). There are several challenges inherent in interpreting these experiments. For example, signaling through the lymphotoxin- $\beta$ receptor (LT $\beta R$ ) by $\mathrm{LT} \alpha / \beta$ heterotrimer is critical during lymphoid development, and both $\mathrm{LT} \alpha^{-/-}$and $L T \beta^{-/-}$mice lack all or a subset of peripheral LNs (reviewed in ref. 8). In addition, both $L T \alpha$ and $L T \beta$ genes are located within the mouse MHC (9). Since EAE models are often performed on susceptible strains, backcrossing from the

Received for publication April 14, 2003, and accepted in revised form June 24, 2003.

Address correspondence to: Jennifer L. Gommerman, Department of Immunology, University of Toronto, 1 King's College Circle, Medical Research Building Room 5259, Toronto, Ontario M5F 1A8, Canada. Phone: (416) 978-6959; Fax: (416) 978-1938; Email: jen.gommerman@utoronto.ca. Conflict of interest: K. Giza, S. Perper, I. Sizing, A. Ngam-ek, and J.L. Browning are current employees of Biogen Inc., and J.L. Gommerman and C. Nickerson-Nutter are former employees of Biogen Inc. Biogen Inc. is attempting to develop LT $\beta$ R-Ig for the treatment of autoimmune diseases.

Nonstandard abbreviations used: experimental autoimmune encephalomyelitis (EAE); lymphotoxin (LT); lymphotoxin- $\beta$ receptor-Ig fusion protein (LT $\beta \mathrm{R}-\mathrm{Ig})$; pertussis toxin (PTx); nonobese diabetic (NOD); myelin basic protein (MBP); myelin oligodendrocyte glycoprotein (MOG); human gamma globulin (huIgG); relapsing EAE (R-EAE); proteolipid protein (PLP); Luxol fast blue (LFB); Ab-dependent cell cytotoxicity (ADCC); follicular dendritic cell (FDC).
129 strain becomes problematic (10). Even if these factors are controlled by the use of bone marrow chimeras and by studying C57BL/6 LT $\alpha^{-/-}$mice (4), EAE models tested in this context have required the administration of pertussis toxin (PTx), presumably to induce blood-brain barrier permeability. Given that PTx also inhibits $G$ protein-coupled chemokine-receptor signaling (11) and that chemokine levels in the secondary lymphoid tissues are under partial LT control (12), this approach to evaluating the role of LT in EAE may obscure its biological function.

The LT $\beta R$ is known to bind to the ligands LT $\alpha / \beta$ heterotrimer (13), and LIGHT (homologous to lymphotoxins, exhibits inducible expression, and competes with herpes simplex virus glycoprotein D for HVEM, a receptor expressed by $\underline{T}$ lymphocytes) (14). We have used a fusion protein, LT $\beta$ R-Ig, that will effectively block both the LIGHT and LT pathways without the complicating developmental defects observed in the knockouts. Interestingly, administration of LT $\beta$ R-Ig prevents the development of several autoimmune diseases, including experimental murine models for colitis (15), a murine model of rheumatoid arthritis (16), and development of autoimmune insulitis in nonobese diabetic (NOD) mice $(17,18)$. Because these models have a critical T cell component to the pathogenesis of disease, it has been unclear why LT pathway inhibition would have an effect in these autoimmune settings.

LIGHT has been implicated in T cell-driven events, both in the periphery and in the thymus. A second receptor for LIGHT is HVEM, and it has been postulated that LIGHT-HVEM interactions are involved in $\mathrm{T}$ cell interactions with other T cells and DCs (14). 
Transgenic mice expressing LIGHT on T cells develop an autoimmune-like phenotype dominated by intestinal disease, thus LIGHT expression may contribute to T cell-based pathology $(19,20)$. Because LT $\beta R$-Ig is an effective LIGHT inhibitor, it is reasonable to assume that LIGHT binding by LT $\beta$ R-Ig contributes to its aforementioned efficacy in attenuating autoimmune disease. Nonetheless, dissection of the relative roles of LIGHT and LT in T cell-driven disease models has not been achieved in a system with a full complement of LNs and intact lymphoid microenvironments.

To understand why LT $\beta$ R-Ig treatment is efficacious in rodent models of $\mathrm{T}$ cell-mediated autoimmune disease, we have revisited the role of LT in the relatively tractable EAE system. We have analyzed the effects of LT $\beta$ R-Ig in three EAE models; the chronic relapsingremitting proteolipid protein-SJL mouse model, the acute Lewis rat myelin basic protein (MBP) model, and the acute mouse myelin oligodendrocyte glycoprotein-C57BL/6 (MOG-C57BL/6) system that was used previously to analyze the LT-deficient mice. Both an anti-LT $\beta$-blocking $\mathrm{mAb}$ and a LIGHT-specific inhibitor, HVEM-Ig, were used to assess the roles of LIGHT and LT. The results indicate that LT $\beta$ R-Ig decreased disease in models that are not dependent on PTx, thus revealing a previously unappreciated role for the LT pathway in EAE. Furthermore, the LT $\alpha / \beta$ heterotrimer is involved in the pathogenesis of EAE independent of the LIGHT ligand. Lastly, T cell recall responses but not $\mathrm{T}$ cell priming were found to be impaired when LT pathway was inhibited, providing a potential explanation for the role of LT pathway in $\mathrm{T}$ cell-mediated autoimmune diseases.

\section{Methods}

Animals. Female Lewis rats, 6-8 weeks old, were obtained from Harlan Sprague Dawley (Indianapolis, Indiana, USA). Female 6- to 8-week-old SJL, C57BL/6, $\mathrm{BALB} / \mathrm{c}$, and $\mathrm{BALB} / \mathrm{c}$ DO11.10 mice were obtained from The Jackson Laboratory (Bar Harbor, Maine, USA). All animals were housed under specific pathogen-free barrier conditions at Biogen Inc. All protocols were approved by the Biogen Inc. Animal Care and Use Committee. Paralyzed mice and rats were afforded facile access to food and water and given subcutaneous injections of a $2.5 \%$ dextrose solution at $100 \mathrm{ml} / \mathrm{kg}$ as needed.

Reagents. Three forms of murine LT $\beta R$ fused to various Ig Fc domains were employed in these studies. The murine receptor-human IgG-1 fusion protein was described previously, and a second similar form that included a N297Q mutation in the Fc domain was also prepared (21). This latter construct lacks the Fc $\mathrm{N}$-linked glycosylation site and hence has lost the ability to bind FcyRIII (22). A third construct fused the murine receptor to mouse IgG-1 Fc domain. All fusion proteins were produced from $\mathrm{CHO}$ cells, purified by conventional protein A-based affinity chromatography, and contained less than 0.5 endotoxin units per milli- gram of protein. Murine HVEM was cloned by RT-PCR and expressed as a fusion protein with the human IgG-1 Fc domain containing the N297Q mutation. Since this construct bound both human and murine LIGHT expressed on the cell surface in a comparable manner in FACS-binding experiments (data not shown), roughly equivalent binding to rat LIGHT was assumed. In addition, both murine HVEM-Ig and human HVEM-Ig prevent in vitro human LIGHT-mediated killing of $\mathrm{HT} 29$ cells with a similar $\mathrm{ED}_{50}$ (data not shown, $5 \mu \mathrm{g} / \mathrm{ml}$ ). The blocking Armenian hamster anti-murine LT $\beta$ mAb (BBF6) has been described and shown to function in vivo in mice $(23,24)$. The Armenian hamster control anti-KLH hybridoma (HA4/8) was a gift from Donna Mendrick (Harvard Medical School, Brigham and Women's Hospital, Boston, Massachusetts, USA). The ability of anti-LT $\beta$ and LT $\beta$ R-Ig to bind to rat LT was assessed with PMA-activated splenic T cells, and in these FACS analyses of binding to mouse and rat cells the $\mathrm{ED}_{50}$ concentrations were 25 and 14 $\mathrm{ng} / \mathrm{ml}$ with LT $\beta \mathrm{R}-\mathrm{Ig}$ and 0.82 and $1.0 \mu \mathrm{g} / \mathrm{ml}$ with antiLT $\beta$. Briefly, splenocytes were activated with $50 \mathrm{ng} / \mathrm{ml}$ PMA overnight, washed, and then stained with Ab's B220-FITC and CD4-CyC (both from PharMingen, San Diego, California, USA) essentially as described (21). Cells were also stained with anti-LT $\beta$ versus HA $4 / 8$ control followed by PE-conjugated anti-hamster Ab's (Jackson Immunochemicals, West Grove, Pennsylvania, USA) or alternatively LT $\beta$ R-Ig versus human gamma globulin (huIgG) control followed by PE-conjugated anti-human Ab's (Jackson Immunochemicals).

Induction of EAE in Lewis rats. Rats were pretreated on the day before immunization (day -1) and weekly thereafter with intraperitoneal injections of either LT $\beta$ R-Ig (human IgG-1 Fc), HVEM-Ig (human IgG-1 Fc), or polyclonal huIgG (panglobulin; ZLB AG Bioplasma, Bern, Switzerland), which was used at the same concentration as LT $\beta$ R-Ig and HVEM-Ig to control for any potential effects of nonspecific Ab's in this model. Dosing was at $5 \mathrm{mg} / \mathrm{kg}$ unless otherwise described. For treatment with anti-LT $\beta \mathrm{mAb}$ or a hamster-matched isotype control mAb (HA4/8), rats were treated with $5 \mathrm{mg} / \mathrm{kg}$ anti-LT $\beta$ or HA $4 / 8$ at day -2 , day 0 (immunization day), and then subsequently at days 3, 5, and 7. Rats were immunized (day 0) by injection in one hind footpad with an emulsion of guinea pig $\mathrm{MBP}_{68-86}$ peptide (YGSLPQKSQ-RSDENPV; synthesized at Biogen Inc.) in CFA. Briefly, CFA was prepared by combining incomplete Freund's adjuvant (Life Technologies Inc., Grand Island, New York, USA) with finely ground Mycobacterium tuberculosis H37Ra (Difco Laboratories, Detroit, Michigan, USA). The MBP-peptide was diluted to $0.5 \mathrm{mg} / \mathrm{ml}$ in PBS, diluted twofold by an equal volume of CFA, and then the mixture was emulsified so that the final concentrations of peptide and M. tuberculosis were 0.25 $\mathrm{mg} / \mathrm{ml}$ and $4.0 \mathrm{mg} / \mathrm{ml}$, respectively. Each rat received a single subcutaneous injection of $100 \mu \mathrm{l}$ of emulsion totaling $25 \mu \mathrm{g}$ peptide and $400 \mu \mathrm{g}$ mycobacterium for 
each animal. Disease was monitored daily by measuring paralysis according to the following grading system: $0=$ no disease; $0.5=$ half of tail limp; $1.0=$ whole tail limp; $2.0=$ hind-limb weakness; $3.0=$ hind-limb paralysis; $4.0=$ hind-limb plus one front-limb paralysis; $5.0=$ moribund or dead, with disease incidence always at $100 \%$. Within each experiment, a Dunn's test was used to compare multiple groups to the huIgG group, and direct comparisons between two groups were performed with the Mann-Whitney rank-sum test.

Induction of relapsing EAE (R-EAE) in SJL mice. SJL mice were pretreated on day -1 and weekly thereafter with i.v. injections of $100 \mu \mathrm{g}$ of either LT $\beta \mathrm{R}-\mathrm{Ig}$ (murine IgG-1 Fc) or MOPC21 murine IgG-1 control Ab (32 mice per group). The murine IgG-1 construct was used because the blood levels of the human IgG-1 version could not be sustained beyond 1-2 weeks (measured by serum ELISA, data not shown). The injections were performed i.v. to further reduce any potential antigenicity of the LT $\beta R$ - Ig construct. Mice were immunized the following day (day 0 ) by three subcutaneous injections on the back, totaling $100 \mu \mathrm{l}$ of an emulsification of bovine proteolipid protein peptide (PLP $\left.{ }_{139-151}\right)$ (HSLGTKWLGHPDKF; synthesized at Biogen Inc.) in CFA. The final concentrations of peptide and M. tuberculosis were $100 \mu \mathrm{g} /$ mouse and 200 $\mu \mathrm{g} /$ mouse, respectively. Disease was monitored daily in a blinded fashion by measuring paralysis according to the following conventional grading system: $0=$ no disease; 1 = tail limp or slight hind-limb weakness; $2=$ hind-limb weakness; 3 = partial hind-limb paralysis; $4=$ complete hind-limb paralysis; $5=$ complete hind-limb paralysis plus fore-limb paralysis; $6=$ moribund or dead. Disease incidence was approximately $75 \%$ in each group, and subsequently only these animals were monitored. The average disease score was determined for each group. A relapse was defined as 2 consecutive days of a score increase of at least 1.5 relative to the prerelapse score, and the incidence of relapse was indicative of the accumulation of relapses across the cohort over time. Average maximal disease scores were compared between groups using the oneway ANOVA. Relapse frequency between groups was compared using the $z$ test.

Induction of EAE in C57BL/6 mice. Eight- to twelveweek-old C57BL/ 6 mice were pretreated on day -1 and weekly thereafter with intraperitoneal injections of $5 \mathrm{mg} / \mathrm{kg}$ of either LT $\beta$ R-Ig (human IgG- $1 \mathrm{Fc}$ ) or polyclonal human IgG control. Mice $(n=30$ per group) were immunized the following day (day 0 ) by two subcutaneous injections on the back totaling $200 \mu \mathrm{l}$ of an emulsification of $\mathrm{MOG}_{35-55}$ peptide (MEVGWYRSPFSRVVHLYRNGK; Bachem AG, Bubendorf, Switzerland) in CFA. The final concentrations of peptide and $M$. tuberculosis were 150 $\mu \mathrm{g} /$ mouse and $1 \mathrm{mg} /$ mouse, respectively. PTx (400 ng; LIST Biological Laboratories Inc., Campbell, California, USA) was injected intraperitoneally on days 0 and 2 . The experiment was repeated using 500 $\mu \mathrm{g} /$ mouse M. tuberculosis and $200 \mathrm{ng}$ of PTx with similar results (data not shown). Disease was monitored daily by measuring paralysis on a $0-6$ scale as described above. Average maximal disease scores were compared between groups using a one-way ANOVA.

DO11.10 adoptive T cell transfer experiments. For evaluation of antigen-specific (Ag-specific) T cell expansion in vivo, DO11.10 mice were used as a source of OVA peptide-specific $\left(\mathrm{OVA}_{323-339}\right.$-specific) donor $\mathrm{T}$ cells (25). $\mathrm{CD}^{+} \mathrm{T}$ cells were purified by negative selection using mouse-specific CD4 cell recovery columns, according to the manufacturer's specifications (Cedarlane Laboratories Ltd., Hornby, Ontario, Canada). Purity of $\mathrm{CD} 4^{+} \mathrm{T}$ cells was assessed by flow cytometry using CD4-Cyc and CD62L-PE (both from PharMingen) in combination with KJ126-biotin (Caltag Laboratories Inc., Burlingame, California, USA) and streptavidinFITC (PharMingen) to identify DO11.10 T cells. Naive

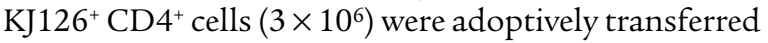
intravenously into nonirradiated, syngeneic, BALB/c wild-type recipients that had been pretreated for 7 days with either control huIgG or LT $\beta$ R-Ig. In some experiments, transferred T cells were prelabeled with $1 \mu \mathrm{M}$ CFSE for 10 minutes at $37^{\circ} \mathrm{C}$. One day following cell transfer, mice were either untreated (control group) or immunized subcutaneously with $50 \mu \mathrm{g}$ of $\mathrm{OVA}_{323-339}$ emulsified in CFA (Difco Laboratories). LT $\beta$ R-Ig and huIgG treatments were continued at 7-day intervals following immunization. Frequency of DO11.10 T cells was determined for each recipient mouse by staining with PE-labeled KJ126 (Caltag Laboratories Inc.). DO11.10 T cells were also stained with Ab's to CD69 and CD25 (PharMingen).

$T$ cell-proliferation assays. For evaluation of the $T$ cell response in the rat EAE model, draining inguinal LNs were harvested from all treatment groups at day 7 and 10 of the disease course. $\mathrm{CD} 4^{+} \mathrm{T}$ cells were purified by negative selection from dissociated $\mathrm{LN}$ cells by passing them through a rat $\mathrm{CD} 4$ cell-recovery column, according to the manufacturer's specifications (Cedarlane Laboratories Inc.). Purity was confirmed by flow cytometry using Ab's to B220, CD4, and CD8 (PharMingen), and preparations were consistently 98\% $\mathrm{CD}^{+} \mathrm{T}$ cells. $\mathrm{T}$ cells were then cultured in 96-well plates at a density of $2 \times 10^{5}$ cells/well with $5 \times 10^{5}$ irradiated (30 Gy) rat control splenocytes per well in a total volume of $200 \mu \mathrm{l}$ of RPMI (Sigma-Aldrich, St. Louis, Missouri, USA) supplemented with 5\% FBS (JRH Biosciences Inc., Lenexa, Kansas), $100 \mathrm{U} / \mathrm{ml}$ penicillin (BioWhitaker Inc., Walkersville, Maryland, USA), $2 \mathrm{mM}$ L-glutamine (BioWhitaker Inc.), and $5 \mu \mathrm{M} 2$-mercaptoethanol (Sigma-Aldrich). Cells were cultured at $37^{\circ} \mathrm{C}$ in $5 \% \mathrm{CO}_{2}$ in the presence or the absence (background) of varying concentrations of MBP-peptide. As a positive control, anti-rat CD3 (PharMingen) was used at a concentration of $5 \mu \mathrm{g} / \mathrm{ml}$ (data not shown). After 72 hours, $100 \mu \mathrm{l}$ of supernatant was collected, and media was replaced with RPMI containing $1 \mu \mathrm{Ci}$ of ${ }^{3} \mathrm{H}$ thymidine for 6 hours. Mean incorporation of thymidine in 
DNA was measured in triplicate wells by liquid scintillation counting. For evaluation of the $\mathrm{T}$ cell response in the SJL R-EAE model, draining inguinal LNs were harvested at day 7 or day 10 and spleens harvested at day 39 or day 59. Single-cell LN suspensions or spleen cell suspensions in which red blood cells had been lysed were plated at a density of $5 \times 10^{5}$ cells/well in a 96-well plate in RPMI in the presence or the absence (background) of varying concentrations of PLP ${ }_{139-151}$. As a positive control, anti-mouse CD3 (PharMingen) was used at a concentration of $5 \mu \mathrm{g} / \mathrm{ml}$ (data not shown). After 72 hours, $100 \mu \mathrm{l}$ of supernatant was collected, and media was replaced with RPMI containing $1 \mu \mathrm{Ci}$ of ${ }^{3} \mathrm{H}$ thymidine for 18 hours. Mean incorporation of thymidine in DNA was measured in triplicate wells by liquid-scintillation counting. For DO11.10 ex vivo T cell responses, draining inguinal $\mathrm{LNs}$ were isolated on day 7 following immunization. $\mathrm{CD}^{+} \mathrm{T}$ cells from recipient mice were purified using a mouse-specific CD4 cell recovery column according to the manufacturer's specifications (Cedarlane Laboratories Inc.). Purity was confirmed by flow cytometry using Ab's to B220, CD4, and CD8 (PharMingen), and preparations were consistently $98 \% \mathrm{CD}^{+} \mathrm{T}$ cells. KJ126 ${ }^{+} \mathrm{T}$ cells $(10,000)$ were plated with 200,000 irradiated BALB/c splenocytes and varying concentrations of $\mathrm{OVA}_{323-339}$ in a total volume of $200 \mu \mathrm{l}$ of RPMI (Sigma-Aldrich). In some cases, $\mathrm{CD}^{+} \mathrm{T}$ cells were prelabeled with CFSE for 10 minutes at $37^{\circ} \mathrm{C}$ and then were stained with PElabeled KJ126 (Caltag Laboratories Inc.) and anti-CD4 (PharMingen) after 3 days in culture with $\mathrm{OVA}_{323-339}$. In other cases, plates were pulsed with $1 \mu \mathrm{Ci}$ of ${ }^{3} \mathrm{H}$ thymidine for 6 hours. Mean incorporation of thymidine in DNA was measured in triplicate wells by liquid scintillation counting.

Cytokine measurement by ELISA. Supernatants from rat and mouse proliferation assays were harvested at 72 hours of culture, and IFN- $\gamma$ concentrations in supernatants were determined by the respective sandwich ELISAs according to the manufacturer's directions (BioSource International, Camarillo, California, USA). Analysis of infiltrates in CNS. CNS-associated leukocytes were isolated from whole rat CNS tissue after heparinsaline perfusion of rats, isolation and homogenization of spinal cords, and Percoll gradient-density purification (Pharmacia Biotech AB, Uppsala, Sweden), as described (26). Cells were incubated with Ab's to rat CD4, CD8, and B220 (all PharMingen). Flow-cytometric data was acquired on a FACScan (Becton Dickinson Immunocytometry Systems, San Jose, California, USA). Histology. Dissected specimens of CNS were obtained from animals perfused with heparin-saline and stored in $10 \%$ buffered formalin. Paraffin-embedded sections of the cervical, thoracic, and lumbar sections of rat and mouse spinal cord were stained with H\&E for light microscopy. Mouse spinal cords were also stained with Luxol fast blue (LFB) and counterstained with cresyl violet. Total cell number and number of apoptotic bodies were manually counted in $\times 400 \mathrm{H} \& \mathrm{E}$ fields from four mice from each treatment group. An average of 562 cells per specimen from the treatment groups and 125 cells per specimen from the untreated group were counted, and the ratio of apoptotic bodies to total cell count was calculated.

\section{Results}

$L T \beta R$-Ig prevents EAE disease development in a rat monophasic model. EAE in Lewis rats is induced by immunization with MBP-peptide in CFA, resulting in an acute monophasic disease that peaks at day 13 and resolves by day 15 . Using this PTx-free EAE model, when animals were treated the day prior to immunization with either polyclonal huIgG or LT $\beta$ R-Ig (human IgG-1 Fc), rats treated with LT $\beta$ R-Ig exhibit very little paralysis
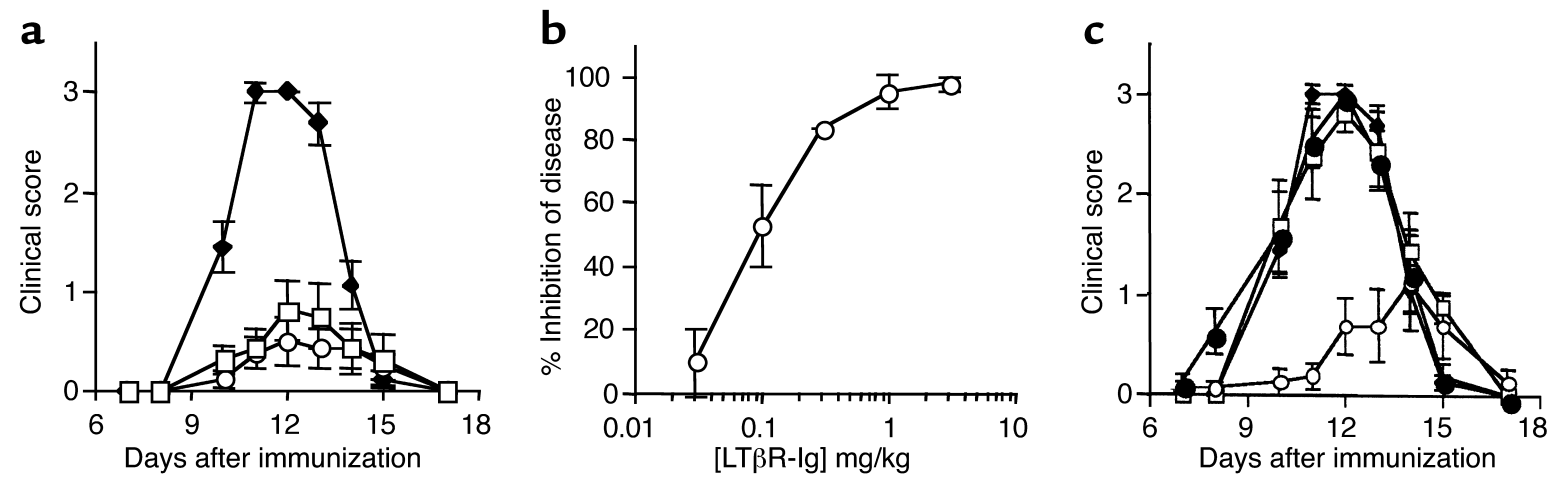

\section{Figure 1}

Disease is prevented by LT $\beta$ R-Ig or anti-LT $\beta$ treatment in an acute rat EAE model. (a) Lewis rats were treated with either control human IgG (diamonds), LT $\beta R$-Ig (circles), or N297Q LT $\beta R$-Ig (squares) 1 day prior to immunization with MBP-peptide in CFA, and disease was scored by measuring tail and limb paralysis. (b) Dose response to LT $\beta R$-Ig was evaluated in the rat EAE model by administering LT $\beta R$-Ig at the indicated dose. The percentage of inhibition of disease was calculated by determining the decrease in clinical score on the peak day of disease. (c) Lewis rats were treated with either control hulgG (diamonds), HVEM-Ig (squares), anti-murine LT $\beta$ (open circles), or control mAb HA4/8 (filled circles) 1 day prior to immunization with MBP-peptide in CFA. Treatment with anti-LT $\beta$ and HA4/8 was continued on days 3 , 5, and 7 after immunization. Eight animals were used for each group, and the experiment was performed three times with similar results. Experiments using anti-LT $\beta$, HVEM-Ig, and HA4/8 were performed two times with similar results. 


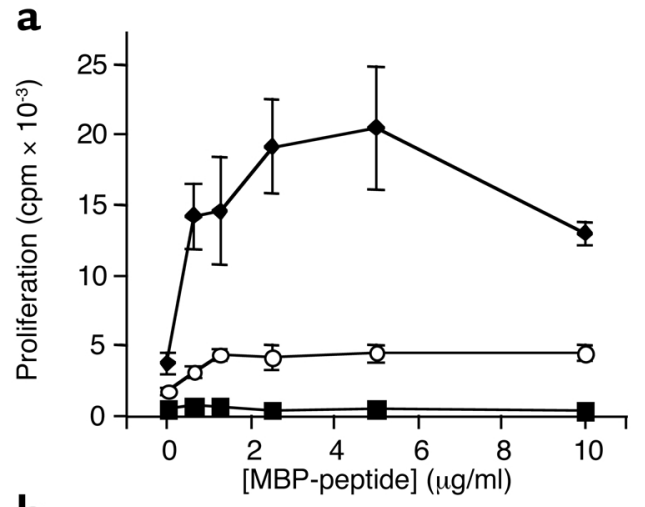

b

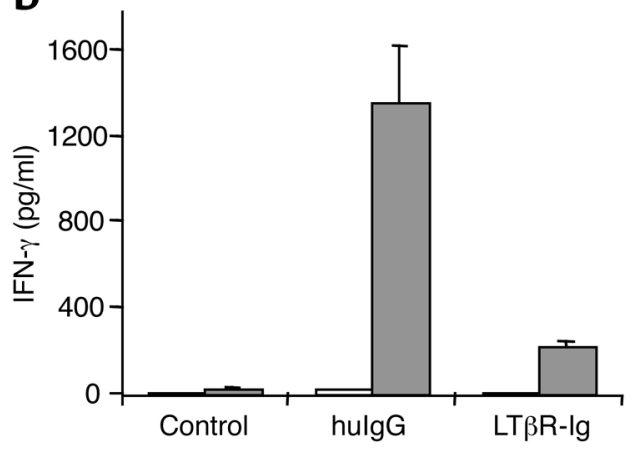

(Figure 1a, open circles), and their median cumulative clinical score was significantly lower than huIgG-treated rats $(P<0.001)$. Importantly, inhibition of disease could be accomplished with relatively low concentrations of LT $\beta$ R-Ig, with $50 \%$ inhibition observed at approximately $0.1 \mathrm{mg} / \mathrm{kg}$ (Figure $1 \mathrm{~b}$ ). Therefore, LT $\beta$ R-Ig is a potent inhibitor of monophasic EAE, a predominantly $\mathrm{T}$ cell-mediated system.

\section{Figure 2}

$\mathrm{CD} 4^{+} \mathrm{T}$ cells from LT $\beta \mathrm{R}$-lg-treated rats are hyporesponsive ex vivo. (a) Pooled $\mathrm{CD}^{+} \mathrm{T}$ cells were isolated at D10 from rats in the EAE model $(n=5)$, stimulated in vitro with irradiated splenocytes, and indicated concentrations of MBP-peptide and proliferation measured by ${ }^{3} \mathrm{H}$-thymidine incorporation. Cells were derived from rats treated in vivo with control hulgG (diamonds), LT $\beta R$-Ig (circles), or from naive, untreated rats as controls (squares). (b) Supernatants from cultures in a ( 0 and $2.5 \mu \mathrm{g} / \mathrm{ml}$ MBP-peptide, white and gray bars, respectively) were collected at 72 hours and measured by ELISA for IFN- $\gamma$ content. The experiment was repeated three times with similar results and also performed at day 7 with similar results.

Because the LT $\beta$ R decoy agent is an Ig-fusion protein, it was important to determine if the mechanism of action was simply due to effector cell-mediated depletion of encephalogenic $\mathrm{T}$ cells by Ab-dependent cell cytotoxicity (ADCC), since activated lymphocytes transiently express LT heterotrimer (13). Therefore, we tested a LT $\beta$ R-Ig construct containing a point mutation N297Q that removes a glycosylation site critical for FcR $\gamma I I I$ receptor engagement (22). Comparison of the disease course with the wild-type construct versus the mutant revealed no significant differences in the cumulative median clinical scores (Figure 1a, open squares versus open circles; $P=0.104)$, and the doseresponse curves were identical down to the lowest dose of aglycosyl-LT $\beta R-I g$ tested $(0.3 \mathrm{mg} / \mathrm{kg}$; data not shown). Hence, ADCC is not required for LT $\beta$ R-Igmediated inhibition of disease in the rat EAE model. Efficacy of $L T \beta R$-Ig in rat EAE is dependent on $L T \alpha \beta$ binding to LT $\beta R$. Recent studies examining LIGHT-overexpressing mice suggest that this TNF family member may be involved in T cell-driven autoimmunity $(19,20)$. Because

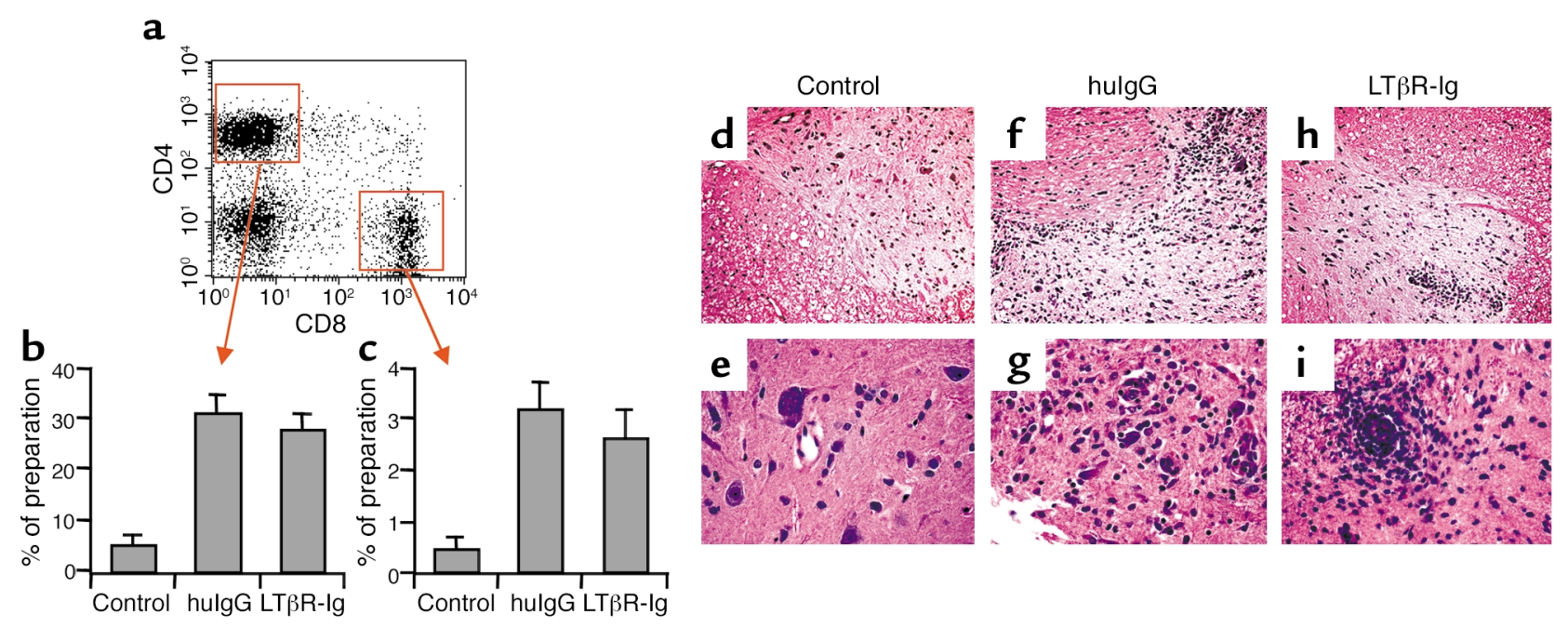

Figure 3

Lymphocyte infiltrates are detected in the spinal cords of day-13 EAE rats in both groups; however, the positioning of infiltrates in LT $\beta R$ Ig-treated rats is altered. FACS analysis of lymphocytes obtained from the spinal cords is shown in $\mathbf{a}$. The percentage of CD4+ $(\mathbf{b})$ and $C D 8^{+}$ (c) for all cells in the lymphoid size gate was compared between treatment groups, where control rats were naive and untreated. Mean and standard deviation of five separate animals per group is shown. Spinal cords were also harvested, fixed, tangential paraffin sections stained with $\mathrm{H} \& \mathrm{E}$, and visualized at $\times 50(\mathbf{d}, \mathbf{f}, \mathbf{h})$ or $\times 400(\mathbf{e}, \mathbf{g}, \mathbf{i})$ with a Leica microscope. Unimmunized naive rats $(\mathbf{d}$ and $\mathbf{e})$ were compared with control hulgG-treated rats ( $\mathbf{f}$ and $\mathbf{g}$ ) or LT $\beta$ R-Ig-treated rats ( $\mathbf{h}$ and $\mathbf{i}$ ). The experiments were performed twice with similar results. 


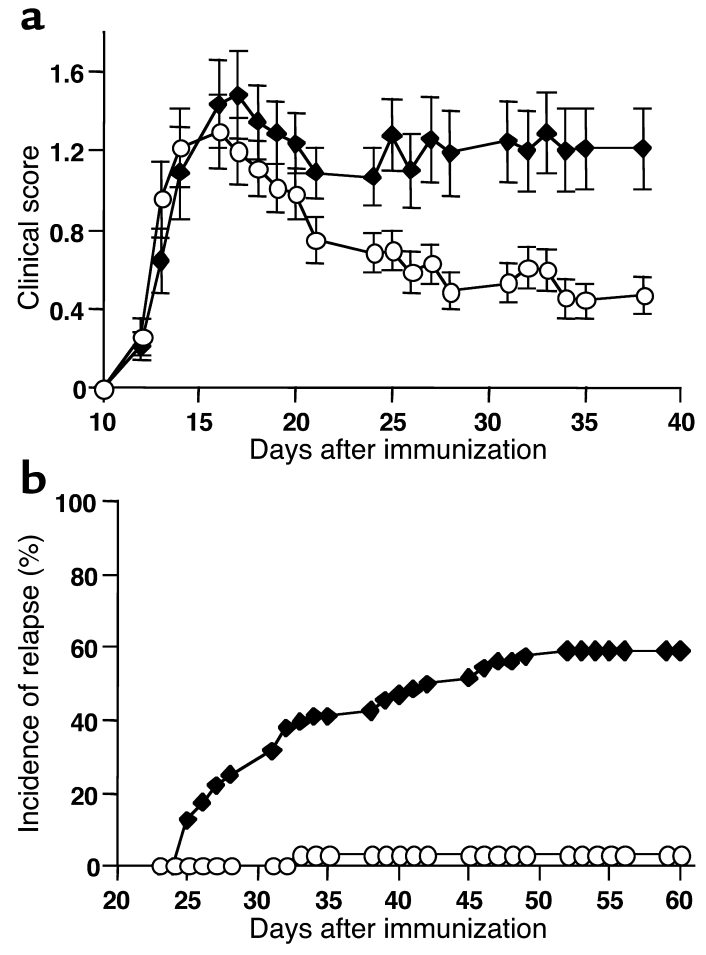

LT $\beta$ R-Ig will bind to LIGHT and hence block HVEM receptor/LIGHT ligand interactions, the efficacy observed with LT $\beta$ R-Ig treatment could be due to the inhibition of either or both the LT and LIGHT pathways. To distinguish between these possibilities, two reagents were tested in rat EAE: an HVEM-Ig fusion decoy protein that will inhibit LIGHT/LT $\beta$ R interactions without affecting $L T \alpha / \beta$-LT $\beta R$ interactions and a blocking $m A b$ specific for LT $\beta$. Accordingly, animals were treated the day prior to immunization with either HVEM-Ig compared with the huIgG control or anti-LT $\beta$ versus a hamster monoclonal control HA4/8. Disease developed in both the huIgG and HA4/8 cohorts, as expected (Figure $1 \mathrm{c}$, filled diamonds and circles, respectively); however, HVEM-Ig administration had no effect on disease (open squares), despite its ability to bind to LIGHT and affect LIGHT-mediated killing in vitro (see Methods). Furthermore, analysis of HVEM-Ig levels in mouse blood showed that this reagent had good pharmacokinetic properties comparable to LT $\beta$ R-Ig (data not shown). While LIGHT binding should be blocked in vivo with this construct, we lack an in vivo control system that is responsive to this construct. Thus, LT-mediated signals through LT $\beta$ R are sufficient to induce disease in the absence of LIGHT binding. In contrast to HVEM-Ig treatment, antiLT $\beta$-treated rats exhibit very little paralysis (open circles) $(P<0.0003$; anti-LT $\beta$ compared with HA4/8 at day 12 , peak disease). Therefore, signaling of LT $\beta \mathrm{R}$ through the $L T \alpha / \beta$ heterodimer is critical for CNS pathogenesis in this EAE model, and LIGHT cannot compensate for the absence of $L T \alpha / \beta$-mediated signaling.

$L T \beta R$-Ig treatment in vivo results in impaired $T$ cell responses ex vivo. Because the rat EAE model is predominantly $\mathrm{T}$

\section{Figure 4}

Relapses but not acute disease are prevented by LTRR-Ig treatment in a chronic murine EAE model. SJL mice were treated with control hulgG (diamonds) or LT $\beta$ R-Ig (circles) 1 day prior to immunization with PLP ${ }_{139-151}$ in CFA. Limb paralysis was scored in all phases of the disease and is represented here as the mean score throughout the cohort (a), and the incidence of relapse was measured beginning on day 20 (b). The experiment was performed on 32 animals per group and was performed twice with similar results.

cell driven $(27,28)$, we wanted to determine if $\mathrm{LT} \beta \mathrm{R}-\mathrm{Ig}$ treatment in vivo results in $\mathrm{T}$ cell defects measured ex vivo. Accordingly, $\mathrm{CD}^{+} \mathrm{T}$ cells from inguinal $\mathrm{LNs}$ draining the site of immunization were isolated at day 10 of the disease course. When $\mathrm{CD}^{+}{ }^{+} \mathrm{T}$ cells from huIgG-treated rats were cultured in the presence of MBP-peptide and APCs, a dose-dependent proliferative response was observed (Figure 2a, filled diamonds). $\mathrm{CD}^{+} \mathrm{T}$ cells from LT $\beta$ R-Ig-treated rats, however, demonstrated significantly less proliferation $(P<0.03$ at $2.5 \mu \mathrm{g} / \mathrm{ml}$ MBP-peptide) in response to MBP-peptide (Figure 2a, open circles). Consistent with these results, $\mathrm{T}$ cells from LT $\beta R$-Ig-treated rats secreted significantly less IFN- $\gamma$ in response to MBP-peptide than T cells from huIgG-treated rats ( $P<0.03$ at $2.5 \mu \mathrm{g} / \mathrm{ml}$ MBP-peptide) (Figure $2 \mathrm{~b}$ ). Therefore, LT $\beta R$-Ig treatment during EAE impairs T cell responsiveness to MBP-peptide ex vivo, and this may account for the observed efficacy in the rat EAE model. Similar results were obtained at day 7 after immunization (data not shown).

LT BR-Ig treatment alters the localization of leukocytic infiltrates into the CNS. Immunization of Lewis rats with MBP-peptide in CFA leads to the generation of encephalitogenic $\mathrm{T}$ cells followed by migration of the $\mathrm{T}$ cells into the CNS, where they produce cytokines and chemokines that mediate inflammation. Because LT $\beta$ R-Ig treatment effectively prevented disease in the rat EAE model, we wanted to determine the status of the CNS in these rats. Accordingly, at day 13 of the rat EAE disease course, spinal cords were harvested and the infiltrates were analyzed using both flow-cytometry and histological approaches. In diseased rats, both $\mathrm{CD}^{+}$and $\mathrm{CD}^{+}$lymphocytes are readily detected in

\section{Table 1}

Measured parameters of R-EAE

\begin{tabular}{lcccc}
\hline & $\begin{array}{c}\text { Onset } \\
\text { day }\end{array}$ & $\begin{array}{c}\text { Maximum } \\
\text { score }\end{array}$ & $\begin{array}{c}\text { Day of } \\
\text { peak score }\end{array}$ & $\begin{array}{c}\text { Incidence } \\
\text { of disease }\end{array}$ \\
$\begin{array}{l}\text { Acute disease } \\
\text { MOPC21 } n=32\end{array}$ & 16.06 & 2.89 & 17.69 & $71 \%$ \\
LT $\beta$ R-Ig $n=34$ & 15.44 & 2.54 & 17.03 & $74 \%$ \\
Relapses & & & & \\
MOPC21 $n=32$ & 32.47 & 3.68 & 33.89 & $59 \%$ \\
$\operatorname{LT} \beta R-\lg n=34$ & 32.00 & 2.00 & 32.00 & $3 \%$
\end{tabular}

SJL mice were pretreated with MOPC21 (control murine IgG-1) or LTßR-Ig the day prior to immunization with $\mathrm{PLP}_{139-151}$ in CFA and then treated weekly thereafter. Mice were graded daily in a blinded fashion. The experiment was performed twice with similar results. Parameters represent the mean of all animals over the course of the experiment. 

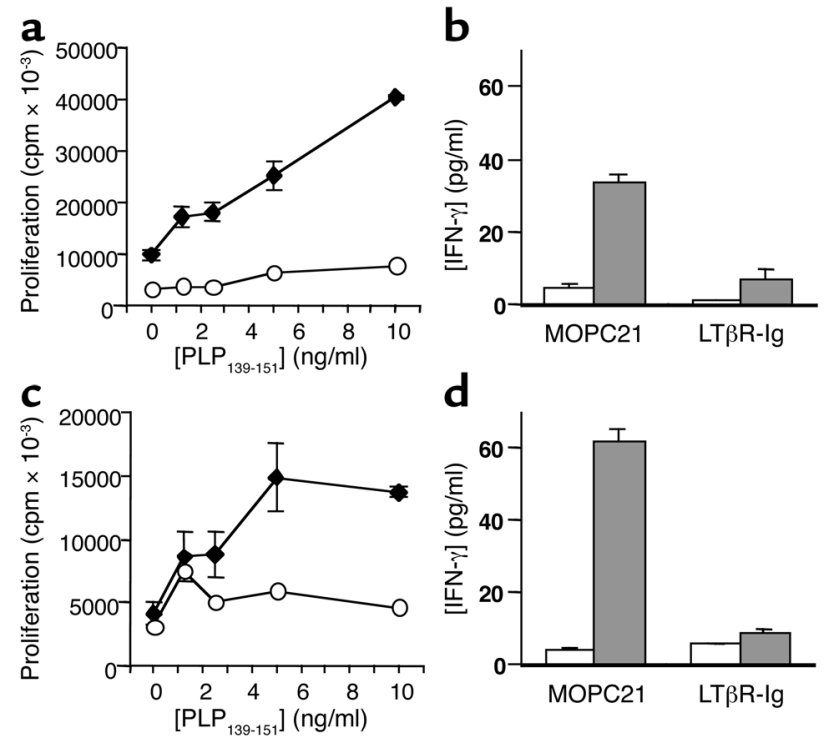

\section{Figure 5}

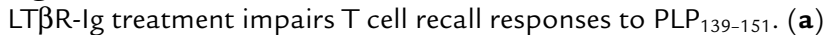
On day 7 after immunization with $\mathrm{PLP}_{139-151}$ in SJL mice, pooled LN cells from control hulgG (diamonds) and LT $\beta$ R-Ig-treated (circles) mice were isolated, stimulated in vitro with $\mathrm{PLP}_{139-151}$, and proliferation was measured by ${ }^{3} \mathrm{H}$-thymidine uptake. (b) Supernatants from cultures in a $\left(0\right.$ and $10 \mu \mathrm{g} / \mathrm{ml} \mathrm{PLP}_{139-151}$, white and gray bars, respectively) were collected at 72 hours and measured by ELISA for IFN- $\gamma$ content. (c) Proliferation data as in a for splenocytes isolated on day 59 after immunization. (d) Supernatants from cultures in $\mathbf{c}$ ( 0 and $10 \mu \mathrm{g} / \mathrm{ml} \mathrm{PLP}$ 139-151 $\left._{1}\right)$ were collected at 72 hours and measured by ELISA for IFN- $\gamma$ content. The experiment was also performed at day 10 and day 39 with similar results.

homogenized spinal cords by flow cytometry (Figure 3a). Interestingly, when huIgG- and LT $\beta$ R-Ig-treated rats were directly compared, no differences were observed in the composition of infiltrates with equivalent percentages of $\mathrm{CD}^{+}$and $\mathrm{CD}^{+} \mathrm{T}$ cells (Figure 3, $\mathrm{b}-\mathrm{c}$ ). In addition, numbers of infiltrating $\mathrm{T}$ cells per isolated spinal cord for control versus LT $\beta$ R-Ig treatment groups were not significantly different $(7,022 \pm 1,743.9$ versus $5,198 \pm 1,111.5$ for $\mathrm{CD}^{+} \mathrm{T}$ cells, $P=0.37$, and $1,616.7 \pm 395.5$ versus $1,013.9 \pm 174.6$ for $\mathrm{CD}^{+} \mathrm{T}$ cells). The location of the infiltrates was also examined by histological analysis of spinal cord tissue (Figure 3, d-i). Infiltrates in spinal cords from huIgG-treated rats appear dispersed through both the gray and the white matter (Figure 3, f and g). In contrast, the infiltrates in the spinal cords from LT $\beta R$-Ig-treated rats appear in a discrete perivascular conformation, and infiltrating leukocytes are not observed in the tissue parenchyma (Figure 3, h and i). Enumeration of apoptotic bodies in the CNS tissue revealed a statistically significant difference between the huIgG versus the LT $\beta$ R-Ig treatment groups ( $14 \%$ versus $3 \%$ of cells counted; $P<0.005$ ), whereas the difference between unimmunized animals and the LT $\beta$ R-Ig treatment group was statistically insignificant ( $1 \%$ versus $3 \%$ of cells counted; $P=0.3$ ). Therefore, inhibition of the LT pathway does not alter the migration of $\mathrm{T}$ cells into the CNS; however, the localization of infiltrates and the number of apoptotic bodies within the tissue are impacted by treatment.

Inbibition of the LT pathway prevents relapses in SJL mice but has no effect on the acute phase. In addition to the monophasic rat EAE model, it was important to assess the efficacy of LT $\beta$ R-Ig in a relapsing form of EAE that similarly does not require administration of PTx. R-EAE is a CD4 Th1-mediated demyelinating disease model induced in SJL susceptible-strain mice by immunization with $\mathrm{PLP}_{139-151}$ in CFA. This regime results in an acute phase of disease that peaks between day 16 and 18 and resolves by day 20 , followed by relapses that occur by day 25 . Therefore, SJL mice were injected the day prior to immunization, and weekly thereafter, with LT $\beta R$-Ig (mouse IgG-1 version) or a control-matched murine IgG-1 protein (MOPC21). Disease scores are represented in Figure 4 as averages across the cohort. Since the relapses occur at varying time points from mouse to mouse, the relapse phase, which occurs after day 25 , is visualized as sustained disease. Examination of disease incidence, maximum score, and day of peak score of the acute phase revealed no differences between the MOPC21 and LT $\beta$ R-Ig treatment groups (Table 1, Figure 4a). After day 25 of the disease course, however, there was a profound reduction in the incidence of disease relapses with LT $\beta$ R-Ig treatment $(P<0.001)$ (Table 1 , Figure $4 \mathrm{~b})$. Therefore, LT $\beta \mathrm{R}-\mathrm{Ig}$ is efficacious in preventing disease reoccurrence in the SJL EAE model.

$L T \beta R$-Ig treatment of R-EAE mice results in $T$ cell byporesponsiveness ex vivo. Ag-induced proliferation and cytokine secretion were measured ex vivo to determine if the efficacy observed with LT $\beta$ R-Ig treatment in the R-EAE model was due to an effect on Th cell differentiation. During the acute phase of the R-EAE disease course, draining LNs were isolated and LN cells were plated with varying concentrations of $\mathrm{PLP}_{139-151}$. Surprisingly, even though the acute phase of disease is unaffected by LT $\beta$ R-Ig treatment, T cell proliferation and IFN- $\gamma$ production in a recall-response assay to $\mathrm{PLP}_{139-151}$ ex vivo are both impaired (Figure 5, a and $b$, respectively, for day 7). Similar results were obtained if LN cells were isolated from day-10 R-EAE mice (data not shown). To assess $T$ cell responses during the relapse phase, on day 59 of the R-EAE disease course, splenocytes from both control MOPC21-treated and LT $\beta R$-Ig-treated R-EAE SJL mice were plated with varying concentrations of $\mathrm{PLP}_{139-151}$ (at later time points of R-EAE, PLP ${ }_{139-151}$ responsiveness is no longer detected in the draining inguinal nodes). Splenocytes from control-treated R-EAE mice responded to $\mathrm{PLP}_{139-151}$ in a dose-dependent manner (Figure 5c, diamonds) and secreted IFN- $\gamma$ (Figure $5 d$ ); however, splenocytes from LT $\beta R$-Ig-treated R-EAE mice were refractory to $\mathrm{PLP}_{139-151}$-mediated proliferation (Figure 5c, open circles) and did not secrete IFN- $\gamma$ (Figure $5 \mathrm{~d}$ ). Therefore, treatment results in impaired ex vivo $\mathrm{T}$ cell responses during both the acute and relapsing phase of the dis- 
ease; however, only during the relapse period is treatment effective at reducing clinical scores.

To examine if the effects on $T$ cells correspond to prevention of inflammation and demyelination in the target tissue, cervical, dorsal, and lumbar sections of R-EAE spinal cords were fixed and examined histologically for infiltration of leukocytes and by LFB staining for demyelination. Compared with the spinal cords of nonimmunized SJL mice (Figure 5, a-d), spinal cords from day-59, immunized control-treated mice exhibit evidence of leukocyte infiltrates in both white and gray matter (Figure 6, e and g). Corresponding to these sites of leukocyte infiltration, there are severe gaps in the LFB staining, which identifies myelin located in the white matter of the CNS (Figure 6, f and h). In contrast, examination of spinal cords from LT $\beta$ R-Ig-treated R-EAE mice revealed very little leukocyte infiltration (Figure 6, $\mathrm{i}$ and $\mathrm{k}$ ) and minimal myelin degradation (Figure $6, j$ and 1). Hence, no inflammation and demyelination is observed during the relapse period in the R-EAE model of LT $\beta$ R-Ig-treated mice.

$L T \beta R$-Ig treatment does not affect in vivo expansion of $A g$ specific T cells; however, subsequent ex vivo responses to Ag are diminished. Given that $\mathrm{T}$ cells from LT $\beta \mathrm{R}-\mathrm{Ig}$-treated rats are hyporesponsive to MBP-peptide ex vivo, one possibility is that in the face of LT inhibition, in vivo priming of $\mathrm{T}$ cells does not occur. We suspected that this was not the case, since the acute phase in R-EAE was unaffected by LT $\beta$ R-Ig treatment. To track Ag-specific T cell clones in vivo, we used the BALB/c-DO11.10 T cell transgenic system (25). In this system,

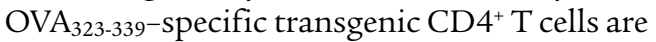
transferred to $\mathrm{BALB} / \mathrm{c}$ recipients that are subsequently immunized with $\mathrm{OVA}_{323-339}$. Because the EAE models we have studied require CFA adjuvant, we similarly immunized BALB/c recipients with $\mathrm{OVA}_{323-339}$ emulsified in CFA. $\mathrm{BALB} / \mathrm{c}$ recipients were pretreated with either LT $\beta$ R-Ig or control protein prior to $\mathrm{T}$ cell transfer and immunization. The expansion of

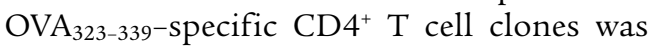
then monitored by FACS using the clonotypic $\mathrm{Ab} \mathrm{KJ} 126$. As controls, animals received $\mathrm{KJ} 126^{+}$ $\mathrm{T}$ cells, but were not immunized with $\mathrm{OVA}_{323-339}$. These animals demonstrated a consistent level of $\mathrm{KJ}^{126^{+}} \mathrm{T}$ cells in the LNs throughout the time course of the experiment, whether they were untreated (Figure $7 \mathrm{a}$ ) or treated with LT $\beta R-\operatorname{Ig}$ (data not shown). In contrast, $\mathrm{KJ} 126^{+} \mathrm{CD}^{+} \mathrm{T}$ cells transferred to control-treated $\mathrm{BALB} / \mathrm{c}$ mice immunized with $\mathrm{OVA}_{323-339-\mathrm{CFA}}$ were found to expand in vivo as a percentage of overall $\mathrm{CD}^{+} \mathrm{T}$ cells. Although inhibition of the LT pathway resulted in defects in $\mathrm{CD}^{+} \mathrm{T}$ cell responses to MBP and PLP peptides ex vivo, we saw no evidence of impaired clonal expansion of Ag-specific DO11.10 T cells in vivo in terms of the per- centage of CD4 ${ }^{+} \mathrm{T}$ cells that were $\mathrm{KJ} 126^{+}$(Figure 7a). The number of $\mathrm{KJ} 126^{+} \mathrm{T}$ cells in all four draining $\mathrm{LNs}$ was also similar for the control huIgG treatment group versus the LT $\beta$ R-Ig treatment group $\left(4.0 \times 10^{5}\right.$ versus $5.7 \times 10^{5}$ at day $5, \mathrm{P}=0.1$, and $4.4 \times 10^{5}$ versus $3.0 \times 10^{5}$ at day $7, \mathrm{P}=0.15$ ). Clonal expansion of DO11.10 T cells in LT $\beta$ R-Ig-treated recipients was not simply due to a small population of proliferating cells since CFSElabeled DO11.10 T cells exhibited a loss of CFSE label over time that was comparable to that seen in controltreated recipients (Figure 7, b, middle panel versus lower panel). In this figure, $\mathrm{KJ} 126^{+}$cells are compared for CFSE labeling at day 5 after immunization. By day 7 after immunization, the majority of the CFSE label is lost (data not shown). Furthermore, transient expression of $\mathrm{T}$ cell activation marker CD69 was observed on DO11.10 T cells from both huIgG- and LT $\beta R$-Ig-treated recipient mice (data not shown). $\mathrm{CD}^{+} \mathrm{T}$ cell responses to $\mathrm{OVA}_{323-339}$ were also evaluated in an in vitro Ag recall assay. Despite normal $\mathrm{T}$ cell expansion in vivo, DO11.10 T cells from LT $\beta$ R-Ig-treated BALB/c recipients responded suboptimally to $\mathrm{Ag}$ at day $7 \mathrm{fol}-$ lowing immunization (Figure 7c). Using CFSE labeling, the defect in Ag-driven recall responses can also be con-
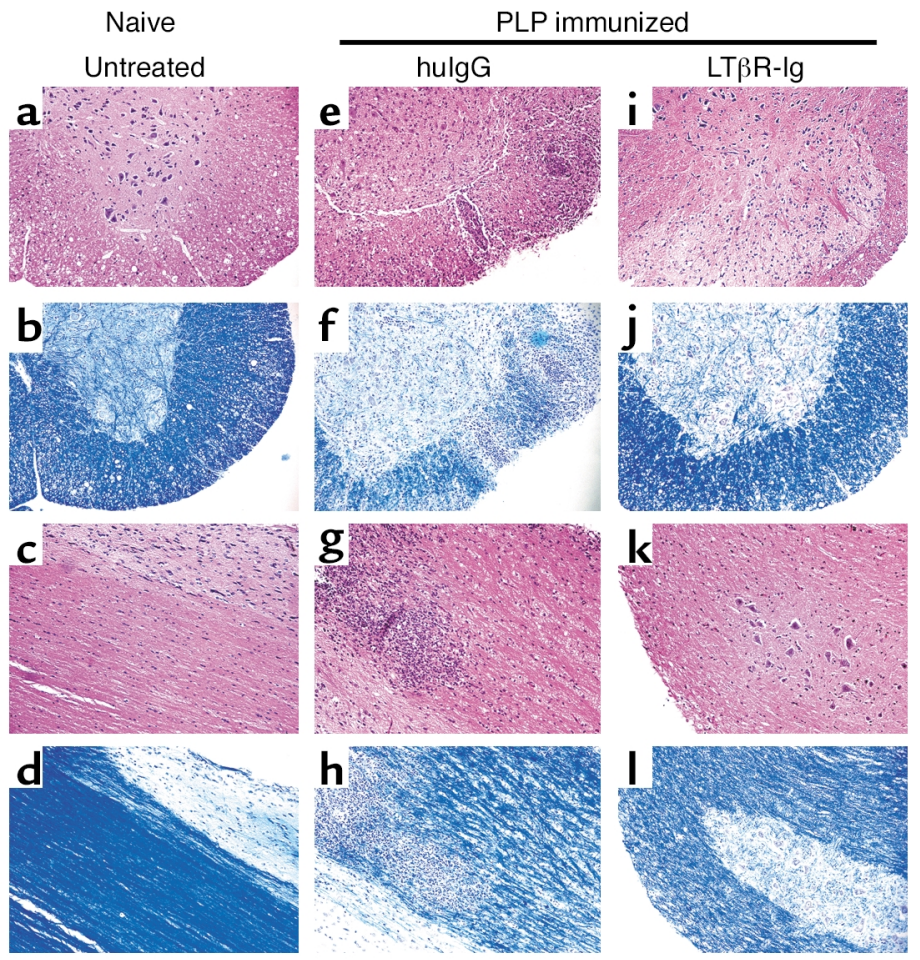

Figure 6

Infiltrates are detected in the CNS of day-59 EAE mice in control IgG but not LT $\beta$ R-Ig-treated mice. Infiltrates and demyelination were compared between untreated naive SJL mice and control hulgG- or LT $\beta R$-Ig-treated SJL mice

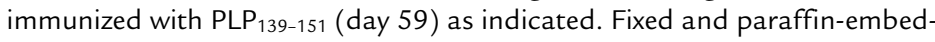
ded spinal cords were sectioned both tangentially $(\mathbf{a}, \mathbf{b}, \mathbf{e}, \mathbf{f}, \mathbf{i}, \mathbf{j})$ and longitudinally (c, d, $\mathbf{g}, \mathbf{h}, \mathbf{k}, \mathbf{I})$, stained with either $\mathrm{H} \& \mathrm{E}(\mathbf{a}, \mathbf{c}, \mathbf{e}, \mathbf{g}, \mathbf{i}, \mathbf{k})$ or with LFB for evaluation of myelin degradation $(\mathbf{b}, \mathbf{d}, \mathbf{f}, \mathbf{h}, \mathbf{j}, \mathbf{I})$, and visualized at $\times 50$ with a Leica microscope. Representative sections from five animals are shown. Similar results were obtained at day 39 after immunization. 
a
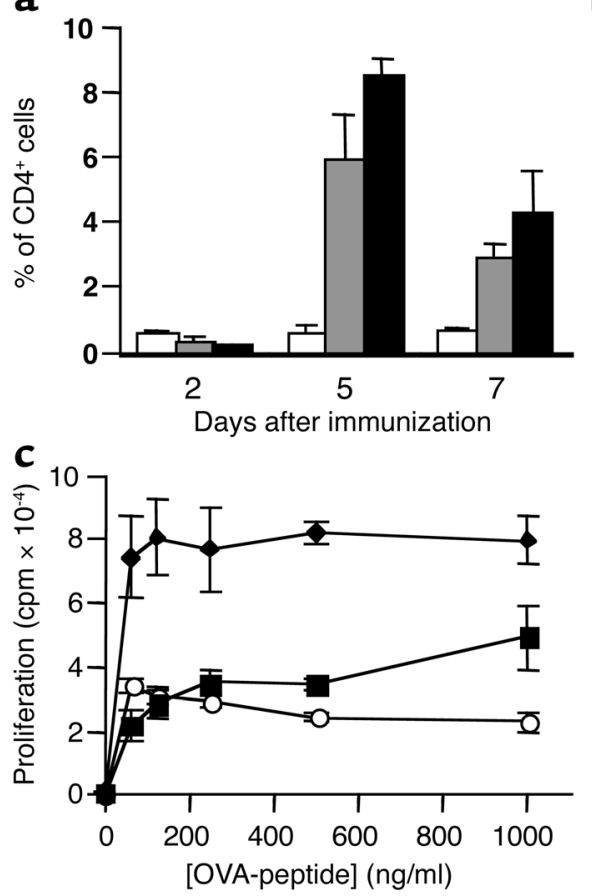

d

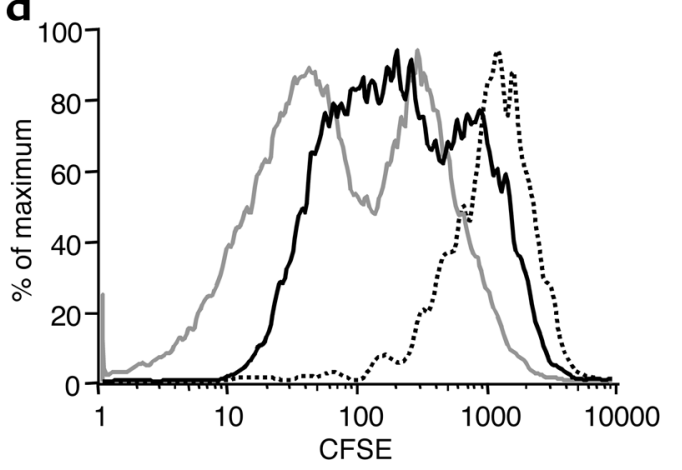

Figure 7

$\mathrm{KJ} 126^{+}$DO11.10 T cells expand normally in vivo in $L T \beta R$-Ig-treated mice, but ex vivo recall responses are impaired. (a) DO11.10 T cell expansion in vivo at days 2, 5, and 7 after immunization is represented as percentage of $\mathrm{CD}^{+} \mathrm{T}$ cells that are $\mathrm{KJ} 126^{+}$. DO $11.10 \mathrm{~T}$ cells were transferred to control hulgG-treated (gray bars) or LT $\beta R$-lg-treated (black bars) $\mathrm{BALB} / \mathrm{c}$ recipients, and the mice were then immunized with $\mathrm{OVA}_{323-339}$ plus CFA (gray and black bars) or not immunized (white bars). (b) Proliferation of DO11.10 T cells was assessed in vivo by prelabeling $\mathrm{KJ} 126^{+}$ $\mathrm{CD}^{+}{ }^{+} \mathrm{T}$ cells with CFSE and transferring these cells to recipients that were not immunized (top panel) or immunized with $\mathrm{OVA}_{323-339}$ plus CFA and treated with hulgG (middle panel) or LT $\beta R$-Ig (bottom panel) as in a. A representative FACS plot 5 days after immunization is shown here, and in each experiment five immunized animals (both treatment groups) and three unimmunized animals were evaluated separately. (c) Proliferation of $\mathrm{CD}^{+} \mathrm{T}$ cells from control hulgGtreated mice (diamonds) was compared with that of LTRR-Ig-treated mice at day 7 (circles). $C D 4^{+} T$ cells from nonimmunized mice were used as controls (squares). These experiments were performed three times with similar results. (d) Proliferation of $\mathrm{CD} 4^{+} \mathrm{KJ} 126^{+}$ $T$ cells was assessed using CFSE labeling at day 7. $\mathrm{CD} 4^{+} \mathrm{KJ} 126^{+} \mathrm{T}$ cells from control hulgGtreated mice stimulated with $\mathrm{OVA}_{323-339}$ (gray line) were compared with that of LT $\beta R$-Igtreated mice (black line) and unstimulated LN cells (dotted line). These data are representative of three separate mice. firmed. Specifically, CFSE prelabeled $\mathrm{KJ} 126^{+} \mathrm{T}$ cells from control-treated recipient mice lose the CFSE label after 3 days in culture with $\mathrm{OVA}_{323-339}$ (Figure $7 \mathrm{~d}$, gray line), whereas $\mathrm{KJ} 126^{+}$cells from $\mathrm{LT} \beta \mathrm{R}-\mathrm{Ig}$-treated recipient mice proliferate much less in response to OVA $_{323-339}$ (Figure $7 \mathrm{~d}$, black line). Thus, these data demonstrate that $\mathrm{T}$ cell priming in vivo is not affected by LT $\beta R$-Ig treatment; however, ex vivo recall responses are sensitive to LT inhibition.

$L T \beta R$-Ig treatment fails to protect against EAE when disease is induced in the presence of PTX. We have postulated that the role of LT pathway in EAE is best elucidated in the absence of PTx and that the use of PTx in previous studies obscured the involvement of this pathway. Accordingly, we have tested the efficacy of LT $\beta$ R-Ig in a model of EAE that employs PTx. C57BL/6 mice were immunized with $\mathrm{MOG}_{35-55}$ in CFA and injected on days 0 and 2 with PTx. Animals that were pretreated with LT $\beta R-I g$ exhibited disease parameters similar to those pretreated with huIgG (Figure 8a), and weight loss due to disease was also similar (Figure 8b). Specifically, in both groups ( $n=29$ for each group), disease onset was 10 days after immunization, and incidence was $100 \%$. The day of peak score in the LT $\beta R$-Ig group was earlier than the huIgG-treated group (day 17 versus day 19), but overall there was no statistically significant difference in mean clinical score during the peak disease period on days 16, 18 , or $19(P=0.07, P=0.24$, and $P=0.16$, respectively). Only on day 17 was there a statistically significant difference in scores $(P<0.0001)$, and this was due to a disproportionate number of mice in the LT $\beta R$-Ig group that needed to be euthanized (score of 6).

\section{Discussion}

We have analyzed the role of LT in EAE by pharmacological inhibition of the LT pathway with a decoy receptor, LT $\beta$ R-Ig. This approach allowed us to execute EAE models in LN-competent animals of disease-susceptible backgrounds. Our results show that administration of LTßR-Ig profoundly inhibits both an acute monophasic form of EAE as well as relapses in a chronic EAE model. These results are significant for several 

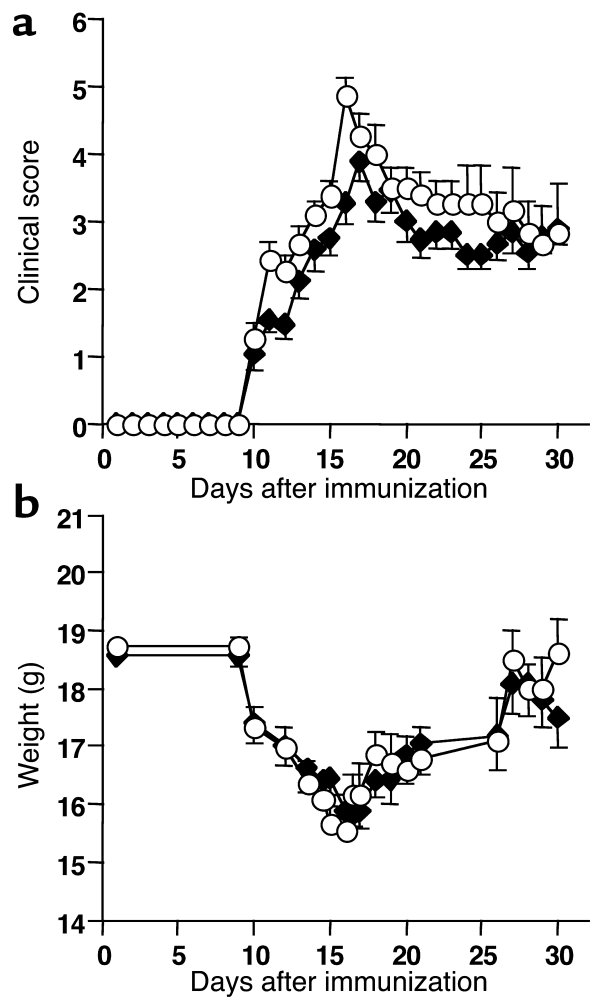

\section{Figure 8}

LT $\beta$ R-Ig treatment does not prevent EAE in a PTx-dependent model. (a) C57BL/ 6 mice were treated with control hulgG (diamonds) or LT $\beta$ R-Ig (circles) 1 day prior to immunization with $\mathrm{MOG}_{35-55}$ in CFA followed by injection of PTx on days 0 and 2. Limb paralysis was scored in all phases of the disease, and if animals were euthanized, they were given a score of 6 on that day of the study. Otherwise, scores reflect only viable animals. (b) Accompanying weight measurements for the experiment in $\mathbf{a}$. The experiment was performed on 30 animals per group and repeated with similar results using less CFA and PTx.

reasons. First, LT $\beta R$-Ig is a dual-pathway inhibitor binding to both surface LT and to the second ligand, LIGHT (14). Inhibition of LIGHT binding to either LT $\beta R$ or HVEM is an attractive mechanism to explain the activity of LT $\beta$ R-Ig in multiple models, yet here we have shown that activity of LT independent of LIGHT must be critical for $\mathrm{T}$ cell function in EAE. Secondly, in previous studies with LT-deficient mice, LT $\alpha$ and, less so, $\mathrm{LT} \beta$ were shown to be required for the development of MOG-EAE; however, in a separate study, MOG-EAE was shown to progress normally in chimeric mice with $L T \alpha$-deficient lymphocytes $(4,6)$. Here, using two EAE models that do not use PTx, we show that the LT pathway clearly plays a role in EAE pathogenesis. This observation underscores the need to examine multiple models of EAE. Finally, LT $\beta$ R-Ig treatment impairs T cell recall responses, suggesting an important role for the LT pathway in $\mathrm{T}$ cell function.

LIGHT may regulate $\mathrm{T}$ cell activation because it has been shown to mediate $T$ cell costimulation (14), and overexpression of LIGHT results in T cell hyperactivation and autoimmunity $(19,20)$. As such, inhibition of
LIGHT was an obvious candidate mechanism to explain the activity of LT $\beta$ R-Ig in T cell-based systems. This work shows, however, that the role of LIGHT in EAE is unlikely since administration of HVEM-Ig that binds to LIGHT in vitro and should block HVEMLIGHT interactions in vivo failed to prevent monophasic EAE. Furthermore, since a mAb specific for LT $\beta$ strongly suppressed rat EAE, LT $\alpha / \beta$-LT $\beta$ R interactions rather than LIGHT-LT $\beta R$ interactions are critical to disease pathogenesis, and this agrees with the recent observation that LT $\alpha / \beta$-LT $\beta$ R interactions are essential for CD8-mediated intestinal transplant rejection (23). Given the antigenicity of the hamster anti-LT $\beta$ used in this analysis, use of this reagent in the more chronic models was not possible. Lastly, human LT $\beta R$ binds to mouse LT with a lower affinity, yet will bind to human and mouse LIGHT with comparable affinity (ref. 21 and unpublished data). Since this human LT $\beta$ R-Ig agent will efficiently bind only rodent LIGHT but not rodent $L T \alpha / \beta$ in vivo, its effect in the rat EAE model was evaluated, and the efficacy of this fusion protein in preventing disease was found to be poor (data not shown). Taken together, these results suggest that LIGHT is not a major contributor to EAE pathogenesis. This surprising result represents, we believe for the first time, a delineation of these two ligands in an autoimmune disease model without the complications of developmentally altered microenvironments or the absence of LNs. Clearly, these results point toward a fundamental role of LT in T cell biology.

While the LT/LIGHT pathway has been linked to several T cell-driven systems $(15,17,18,29,30)$, direct unambiguous genetic evidence supporting the involvement of the LT pathway in T cell-driven autoimmunity does not exist. LT-deficient mice have reduced levels of EAE disease as well as autoimmune myasthenia gravis; however, these observations are complicated by the lack of draining LNs $(6,31,32)$. Analysis of chimeric mice possessing LN-but lacking LT-expressing lymphocytes did not reveal a role for LT in MOG-induced EAE (4). The choice of model(s), and more specifically the use of PTx, could explain the observed differences with this study. When we tested LT $\beta$ R-Ig in the same PTx-dependent EAE model, it failed to protect from disease. How PTx could circumvent the role of the LT pathway in the pathogenesis of these models is unclear; however, chemokine signaling will be inhibited by these amounts of PTx (11). Since LT $\beta R$ signaling is linked to the expression of several chemokines, it is reasonable to speculate that the role of LT in EAE is interwoven with chemokine regulation (12). Similarly, recent evidence has shown that modifying the level of PTx alters the susceptibility to EAE in TNF-deficient mice (33). Taken together, the LT pathway appears to be critical for CFA-driven EAE and most likely other versions of CFA-driven autoimmune disease $(16,31)$.

We observed that Ag recall responses in vitro were inhibited in both the acute and chronic EAE models, 
indicating that the development of a mature $\mathrm{T}$ cell response in vivo was impaired. Our data suggest that the early stages of $\mathrm{T}$ cell priming and expansion are impervious to LT $\beta \mathrm{R}-\mathrm{Ig}$ treatment for two reasons. Firstly, the acute-phase disease of EAE in the SJL mouse, which is T cell mediated, is clearly not affected by LT $\beta R$-Ig treatment, whereas subsequent relapses are strongly inhibited. We tested whether this was due to an inability to generate $\mathrm{T}$ cell responses to other EAE autoepitopes such as $\mathrm{PLP}_{178-191}$ and $\mathrm{MBP}_{84-104}$ (epitope spreading) (34). In our hands, however, ex vivo $\mathrm{CD}^{+} \mathrm{T}$ cell responses to these peptides in control-treated animals were very weak, and therefore differences between treatment groups were uninterpretable (data not shown). Secondly, using the DO11.10 T cell transgenic system, LT $\beta$ R-Ig treatment had no effect on T cell priming and expansion in vivo.

Other TNF family members have been implicated in later-phase $\mathrm{T}$ cell responses. Mice deficient in 4-1BB (CD137-deficient) exhibit normal primary responses to influenza; however, $\mathrm{CD}^{+} \mathrm{T}$ cell expansion and $\mathrm{CTL}$ function is reduced following the secondary response (35). Furthermore, OX40 (CD134) agonism in synergy with LPS signaling was found to profoundly increase the number of long-lived Ag-specific CD4+ memory $\mathrm{T}$ cells (36). We speculate that the LT pathway is necessary for the maturation/sustenance of an encephalogenic $\mathrm{T}$ cell response, and the lack of an ex vivo recall response would appear to be one manifestation of this phenomenon. Specifically, the defect in sustaining $T$ cell responses could reflect impaired maturation of primed $T$ cells into functional effector cells. In agreement with this hypothesis, NOD mice that were backcrossed to an LT $\beta$ R-Ig transgenic mouse demonstrate infiltration of $\mathrm{T}$ cells into pancreatic islets; yet, this appears to be uncoupled from ex vivo $\mathrm{T}$ cell activation and disease (17).

How is the LT pathway involved in effector $\mathrm{T}$ cell maturation? The role of LT is well described in the spleen where it serves to constitutively maintain certain microenvironments such as the marginal zone and the reticulum in the follicles. This picture is less clear in the LNs, although the follicular dendritic cell (FDC) networks are under LT control in these organs (37, 38). LT $\beta$ R-Ig induces rapid changes in FDC networks, while other changes, such as DC scattering/reduction and the collapse of the splenic marginal zone, require 10-14 days of continual LT pathway inhibition $(24,39,40)$. We speculate that certain elements of the microenvironment in the draining LNs are changed in the absence of LT signaling in the adult mouse. These changes lead to altered timing or positioning of the various cell types that need to interact efficiently to propagate a mature $T$ cell response. There are several cellular and molecular players that may be affected by an altered lymphoid microarchitecture. First, affects on DCs could account for the efficacy of LT RR-Ig in EAE. DCs have been shown to express LT $\beta R$ (41), which signals by activating NFKB (42) (reviewed in ref. 43). It is possible that activation of LT $\beta$ R on DCs by LT expressing activated $T$ cells potentiates ongoing immune responses in the same way that CD40 costimulation enhances DC function (44). Secondly, levels of chemokines such as CCL21 are decreased following LT $\beta$ R-Ig treatment, at least in the spleen $(12,23)$, and this chemokine attracts maturing DCs into the secondary lymphoid tissues (reviewed in ref. 45). Thirdly, the reticulum in the LN provides an organized microenvironment that serves to position and probably retain cells to enhance interactions, and regulation of the status of this reticulum by the LT pathway is relatively unexplored. Taken together, miscued cellular interactions or mispositioned accessory cells that are a consequence of $\mathrm{LT}$ inhibition in adult animals may result in inefficient maturation of effector $\mathrm{T}$ cells. This concept will require further experimentation using Ag-specific systems.

\section{Table 2}

Role of TNF and LT in various models of EAE

\begin{tabular}{|c|c|c|c|}
\hline Model & Mode of inhibition & Effect & Reference \\
\hline \multirow[t]{4}{*}{$\begin{array}{l}\text { Lewis Rat } \\
\text { MBP/CFA } \\
\text { Monophasic }\end{array}$} & $\begin{array}{c}\text { LTßR-Ig } \\
\text { (human IgG Fc } \\
\text { and N297Q Fc) }\end{array}$ & $\begin{array}{l}\text { No disease } \\
\text { No weight loss } \\
\text { Impaired T cell } \\
\text { responses }\end{array}$ & \\
\hline & Anti-LT $\beta$ mAb & $\begin{array}{l}\text { No disease } \\
\text { No weight loss }\end{array}$ & \\
\hline & HVEM-Ig & Normal disease & \\
\hline & TNFR55-Ig & Inhibited disease & $(46)$ \\
\hline $\begin{array}{l}\text { SJL mouse } \\
\text { PLP/CFA } \\
\text { Relapsing/remitting }\end{array}$ & $\begin{array}{c}\text { LTRR-Ig } \\
\text { (murine IgG Fc) }\end{array}$ & $\begin{array}{c}\text { Normal acute phase } \\
\text { No relapses } \\
\text { Impaired T cell } \\
\text { responses ( } 9 \text { weeks) }\end{array}$ & \\
\hline \multirow{5}{*}{$\begin{array}{l}\text { C57BL/ } 6 \text { mouse } \\
\text { MOG/CFA (+PTx) } \\
\text { Monophasic }\end{array}$} & $\begin{array}{c}\text { LTRR-Ig } \\
\text { (human IgG Fc) }\end{array}$ & Normal disease & \\
\hline & $T N F^{-/-}$ & Delayed disease & $(2,3)$ \\
\hline & ${ }^{\mathrm{A}} L T \alpha^{-1-}$ & No disease & (6) \\
\hline & ${ }^{A} L T \beta^{-/-}$ & Impaired disease & $(6)$ \\
\hline & 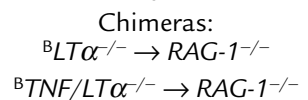 & $\begin{array}{l}\text { Normal disease } \\
\text { Delayed disease }\end{array}$ & $\begin{array}{l}(4) \\
(4)\end{array}$ \\
\hline
\end{tabular}

$\begin{array}{lcc}\text { Transfer of Th1 LT } 13 R-I g & \text { Normal disease } & \begin{array}{c}\text { (N. Ruddle, } \\ \text { personal } \\ \text { EAE CD4 }\end{array} \\ \text { T cell clone } & \text { communication }\end{array}$

LT inhibition of EAE is dependent on the model used. Only models where LT $\beta R$-Ig was used are listed, and not all models used to test TNF inhibition are reported here. AMixed B6/129 background. ${ }^{B}$ C57BL/ 6 background. 
If, in fact, LT $\beta$ R-Ig functions to limit prolonged T cell reactivity to CNS Ag's, then this mechanism is significantly different from that which is observed with TNF inhibition. Whereas LT $\beta \mathrm{R}-\mathrm{Ig}$-treated B6 mice exhibit unimpaired disease in response to MOG plus PTx, TNFdeficient animals exhibit a delayed, chronic form of EAE. Furthermore, $\mathrm{MOG}_{35-55}$-specific $\mathrm{T}$ cell responses are enhanced rather than diminished 9-11 weeks after immunization of TNF-deficient mice, and elevated numbers of $\mathrm{CD} 44^{\text {hi }} \mathrm{CD} 45 \mathrm{RB}^{\mathrm{lo}} \mathrm{CD} 4^{+} \mathrm{T}$ cells are detected in spleens (2). Thus, absence of TNF seems to ameliorate EAE in the early stages, but in the late stages enhanced $T$ cell responses are observed. This is in contrast to the results we have observed for LT $\beta R$-Ig treatment of chronic EAE in SJL mice where relapses rather than acute-phase disease are inhibited and ex vivo recall responses at late time points ( 9 weeks after immunization) are attenuated rather than exacerbated. Therefore, LT and TNF pathways clearly play different roles in EAE pathogenesis, and the examination of EAE models in the absence of PTx has elucidated these differences.

In LT $\beta R$-Ig-treated EAE rats and mice, important differences were noted in the CNS. Leukocyte migration within the CNS was restricted to perivascular location, and migration into the CNS parenchyma was diminished. Therefore, LT $\beta$ R-Ig treatment may also modulate inducible chemokines that are required for migration into diseased tissue. Analysis of gene expression triggered by LT $\beta R$ cross-linking revealed that, in an IFN- $\gamma$ dependent fashion, CXCR3 ligands MIG (CXCL9), IP-10 (CXCL10), and I-Tac (CXCL11) are all strongly induced (M. Lukashev and J. Browning, unpublished observations). Interestingly, induction of EAE in TNFdeficient mice results in a pattern of perivascular cuffing of infiltrates in the CNS similar to that which was observed here in Lewis rats, and the ability of TNF to modulate CXCR3 ligands in the presence of IFN- $\gamma$ is well established (46-48). Thus, despite differences in the ability to modulate late-phase responses in EAE, LT and TNF pathways may share attributes at the level of effector cell migration. Given the expression of $L T \alpha / \beta$ in the human MS-diseased brain and chronically inflamed sites, there may be ample ligand present to trigger chemokine secretion and subsequent leukocyte influx (49-54).

Inhibition of the LT pathway yields different results in each of the three models we tested (summarized in Table 2). It is probable that the absence of efficacy in the MOG-EAE model is due to the administration of PTx. What remains less clear is why the acute phase of the relapsing/remitting model was unaffected by LT $\beta \mathrm{R}-\mathrm{Ig}$ treatment, yet monophasic rat EAE was completely prevented by treatment. Perhaps the effector mechanisms responsible for monophasic EAE compared with the acute phase of R-EAE differ and hence are modulated differently by LT $\beta R$-Ig. In addition, rat EAE could not be prevented if LT $\beta$ R-Ig was administered after disease onset (data not shown). It is assumed in this scenario that once $\mathrm{T}$ cells are activated and polarized to a Th1 phenotype, the proinflammatory effector response is beyond recall. This appears to be true with TNFR55-Ig treatment in the same model (55). Furthermore, if EAE is induced by transfer of preprimed Th1 encephalogenic clones in a PTx-free setting, LT $\beta$ R-Ig also has no effect (N. Ruddle, personal communication). It is likely that LT inhibition is important during the early priming events in order to have an impact on late-phase disease and $\mathrm{T}$ cell recall responses, and in this transfer system, priming is initiated in vitro. Equally puzzling is why LT $\beta \mathrm{R}-\mathrm{Ig}$ treatment of $\mathrm{PLP}_{139-151}$-immunized mice results in impaired $T$ cell recall responses at day 7 and 10 after immunization, but the actual clinical scores during this early phase of disease are insensitive to treatment. Presumably, sufficient priming occurs in LT $\beta$ R-Igtreated PLP $139-151-$-immunized SJL mice and migration of encephalogenic clones to the CNS occurs, but this is uncoupled from ex vivo recall responses.

In conclusion, we have tested three separate models of EAE to arrive at a picture of how LT may be involved in disease progression. Here we have shown that LT $\beta$ R-Ig treatment has no effect on MOG/PTx-induced EAE, but treatment succeeds in preventing monophasic EAE as well as relapses in the SJL/PLP model. This activity appears to be directed primarily at the LT pathway rather than the LIGHT pathway. Suppression of late-phase T cell responses and potentially altered migration of $T$ cells into the target tissues appear to underlie the therapeutic efficacy. Inhibition of this pathway may be a promising strategy for the treatment of MS as well as other autoimmune diseases.

\section{Acknowledgments}

At Biogen Inc. we would like to acknowledge the histology performed by Tom Crowell; the analysis of rat EAE spinal cords by Al Gill; the generation and purification of the receptor-Ig fusion proteins by Konrad Miatkowski, Joe Amatucci, and Werner Meier; the assistance of Henry Hess; Gerry Majeau for bridging analyses; and Evangelia Notidis and Paula Hochman for a critical reading of this manuscript. We also acknowledge Rebecca Greenwald for a critical reading of the manuscript. We thank Cedric Raine and Nancy Ruddle for early experiments performed with LT $\beta$ R-Ig in the SJL system and the Th1 EAE clonal-transfer system, respectively.

1. Frei, K., et al. 1997. Tumor necrosis factor $\alpha$ and lymphotoxin $\alpha$ are not required for induction of acute experimental autoimmune encephalomyelitis. J. Exp. Med. 185:2177-2182.

2. Kassiotis, G., and Kollias, G. 2001. Uncoupling the proinflammatory from the immunosuppressive properties of tumor necrosis factor (TNF) at the p55 TNF receptor level: implications for pathogenesis and therapy of autoimmune demyelination. J. Exp. Med. 193:427-434.

3. Korner, H., et al. 1997. Critical points of tumor necrosis factor action in central nervous system autoimmune inflammation defined by gene targeting. J. Exp. Med. 186:1585-1590.

4. Riminton, D.S., et al. 1998. Challenging cytokine redundancy: inflammatory cell movement and clinical course of experimental autoimmune encephalomyelitis are normal in lymphotoxin-deficient, but not tumor necrosis factor-deficient mice. J. Exp. Med. 187:1517-1528.

5. Ruuls, S.R., et al. 2001. Membrane-bound TNF supports secondary lymphoid organ structure but is subservient to secreted TNF in driving autoimmune inflammation. Immunity. 4:533-543.

6. Suen, W.E., Bergman, C.M., Hjelmstrom, P., and Ruddle, N.H. 1997. A critical role for lymphotoxin in experimental allergic encephalomyelitis. J. Exp. Med. 186:1233-1240. 
7. Probert, L., et al. 2000. TNFR1 signalling is critical for the development of demyelination and the limitation of T-cell responses during immunemediated CNS disease. Brain. 123:2005-2019.

8. Mebius, R.E. 2003. Organogenesis of lymphoid tissues. Nat. Rev. Immunol. 3:292-303.

9. Browning, J.L., et al. 1993. Lymphotoxin beta, a novel member of the TNF family that forms a heteromeric complex with lymphotoxin on the cell surface. Cell. 72:847-56.

10. Steinman, L. 1997. Some misconceptions about understanding autoimmunity through experiments with knockouts. J. Exp. Med. 185:2039-2041.

11. Cyster, J.G., and Goodnow, C.C. 1995. Pertussis toxin inhibits migration of B and T lymphocytes into splenic white pulp cords. J. Exp. Med. 182:581-586.

12. Ngo, V.N., et al. 1999. Lymphotoxin alpha/beta and tumor necrosis factor are required for stromal cell expression of homing chemokines in B and T cell areas of the spleen. J. Exp. Med. 189:403-412.

13. Ware, C.F., VanArsdale, T.L., Crowe, P.D., and Browning, J.L. 1995. The ligands and receptors of the lymphotoxin system. Curr. Top. Microbiol. Immunol. 198:175-218.

14. Granger, S.W., and Ware, C.F. 2001. Turning on LIGHT. J. Clin. Invest. 108:1741-1742. doi:10.1172/JCI200114651.

15. Mackay, F., et al. 1998. Both the lymphotoxin and tumor necrosis factor pathways are involved in experimental murine models of colitis. Gastroenterology. 115:1464-1475.

16. Fava, R.A., et al. 2003. A role for the lymphotoxin/LIGHT axis in the pathogenesis of murine collagen induced arthritis. J. Immunol. 171:115-126.

17. Ettinger, R., et al. 2001. A critical role for lymphotoxin-beta receptor in the development of diabetes in nonobese diabetic mice. J. Exp. Med. 193: $1333-1340$.

18. Wu, Q., et al. 2001. Reversal of spontaneous autoimmune insulitis in nonobese diabetic mice by soluble lymphotoxin receptor. J. Exp. Med. 193:1327-1332.

19. Shaikh, R.B., et al. 2001. Constitutive expression of LIGHT on T cells leads to lymphocyte activation, inflammation, and tissue destruction. J. Immunol. 167:6330-6337.

20. Wang, J., et al. 2001. The regulation of T cell homeostasis and autoimmunity by $\mathrm{T}$ cell-derived LIGHT. J. Clin. Invest. 108:1771-1780. doi:10.1172/JCI200113827.

21. Browning, J.L., et al. 1997. Characterization of lymphotoxin-alpha beta complexes on the surface of mouse lymphocytes. J. Immunol. 159:3288-3298.

22. Isaacs, J.D., Clark, M.R., Greenwood, J., and Waldmann, H. 1992. Therapy with monoclonal antibodies: an in vivo model for the assessment of therapeutic potential. J. Immunol. 148:3062-3071.

23. Guo, Z., et al. 2001. Cutting edge: membrane lymphotoxin regulates CD8(+) $\mathrm{T}$ cell-mediated intestinal allograft rejection. J. Immunol. 167:4796-4800

24. Mackay, F., et al. 1997. Lymphotoxin but not tumor necrosis factor functions to maintain splenic architecture and humoral responsiveness in adult mice. Eur. J. Immunol. 27:2033-2042.

25. Murphy, K.M., Heimberger, A.B., and Loh, D.Y. 1990. Induction by antigen of intrathymic apoptosis of CD4+CD8+TCRlo thymocytes in vivo. Science. 250:1720-1723.

26. Ford, A., Goodsall, A., Hickey, W., and Sedgwick, J.D. 1995. Normal adult ramified microglia separated from other central nervous system macrophages by flow cytometric sorting. J. Immunol. 159:3299-3310.

27. Burns, F.R., et al. 1989. Both rat and mouse T cell receptors specific for the encephalitogenic determinant of myelin basic protein use similar V alpha and $V$ beta chain genes even though the major histocompatibility complex and encephalitogenic determinants being recognized are different. J. Exp. Med. 169:27-39.

28. Holda, J.H., and Swanborg, R.H. 1982. Autoimmune effector cells II. Transfer of experimental allergic encephalomyelitis with a subset of T lymphocytes. Eur. J. Immunol. 12:453-455.

29. Benedict, C.A., et al. 2001. Lymphotoxins and cytomegalovirus cooperatively induce interferon-beta, establishing host-virus detente. Immunity. 15:617-626.

30. Puglielli, M.T., et al. 1999. Reversal of virus-induced systemic shock and respiratory failure by blockade of the lymphotoxin pathway. Nat. Med. 5:1370-1374.

31. Goluszko, E., et al. 2001. Lymphotoxin-alpha deficiency completely pro- tects C57BL/6 mice from developing clinical experimental autoimmune myasthenia gravis. J. Neuroimmunol. 113:109-118.

32. Rennert, P.D., et al. 2001. Essential role of lymph nodes in contact hypersensitivity revealed in lymphotoxin-alpha-deficient mice. J. Exp. Med. 193: $1227-1238$

33. Kassiotis, G., Kranidioti, K., and Kollias, G. 2001. Defective CD4 T cell priming and resistance to experimental autoimmune encephalomyelitis in TNF-deficient mice due to innate immune hyporesponsiveness. J. Neuroimmunol. 119:239-247.

34. Vanderlugt, C.L., et al. 2000. Pathologic role and temporal appearance of newly emerging autoepitopes in relapsing experimental autoimmune encephalomyelitis. J. Immunol. 164:670-678.

35. Bertram, E.M., Lau, P., and Watts, T.H. 2002. Temporal segregation of 4-1BB versus $C D 28$-mediated costimulation: $4-1 \mathrm{BB}$ ligand influences $\mathrm{T}$ cell numbers late in the primary response and regulates the size of the $\mathrm{T}$ cell memory response following influenza infection. J. Immunol. 168:3777-3785.

36. Maxwell, J.R., Weinberg, A., Prell, R.A., and Vella, A.T. 2000. Danger and OX40 receptor signaling synergize to enhance memory $T$ cell survival by inhibiting peripheral deletion. J. Immunol. 164:107-112.

37. Fu, Y.X., and Chaplin, D.D. 1999. Development and maturation of secondary lymphoid tissues. Annu. Rev. Immunol. 17:399-433.

38. Gommerman, J.L., et al. 2002. Manipulation of lymphoid microenvironments in nonhuman primates by an inhibitor of the lymphotoxin pathway. J. Clin. Invest. 110:1359-1369. doi:10.1172/JCI200215975.

39. Mackay, F., and Browning, J.L. 1998. Turning off follicular dendritic cells. Nature. 395:26-27.

40. Wu, Q., et al. 1999. The requirement of membrane lymphotoxin for the presence of dendritic cells in lymphoid tissues. J. Exp. Med. 190:629-638.

41. Browning, J.L., and French, L.E. 2002. Visualization of lymphotoxinbeta and lymphotoxin-beta receptor expression in mouse embryos. J. Immunol. 168:5079-5087.

42. Dejardin, E., et al. 2002. The lymphotoxin-beta receptor induces different patterns of gene expression via two NF-kB pathways. Immunity. 17:525-535.

43. Ghosh, S., and Karin, M. 2002. Missing pieces in the NF-kB puzzle. Cell. 109:81-96.

44. Cella, M., et al. 1996. Ligation of CD40 on dendritic cells triggers production of high levels of interleukin-12 and enhances T cell stimulatory capacity: T-T help via APC activation. J. Exp. Med. 184:747-752.

45. Cyster, J.G. 1999. Chemokines and the homing of dendritic cells to the T cell areas of lymphoid organs. J. Exp. Med. 189:447-450.

46. Dufour, J.H., et al. 2002. IFN-gamma inducible protein 10 (IP-10; CSCL10)-deficient mice reveal a role for IP-10 in effector T cell generation and trafficking. J. Immunol. 168:3195-3204.

47. Fife, B.T., et al. 2001. CXCL10 (IFN-gamma-inducible protein 10) control of encephalitogenic CD4+ T cell accumulation in the central nervous system during experimental autoimmune encephalomyelitis. J. Immunol. 166:7617-7624.

48. Ohmori, Y., et al. 1993. Tumor necrosis factor-alpha induces cell type and tissue-specific expression of chemoattractant cytokines in vivo. Am. J. Pathol. 142:861-870.

49. Agyekum, S., et al. 2003. Expression of lymphotoxin-beta (LT- $\beta$ ) in chronic inflammatory conditions. J. Pathol. 199:115-121.

50. Buckle, G.J., Hollsberg, P., and Hafler, D.A. 2003. Activated CD8+ T cells in secondary progressive MS secrete lymphotoxin. Neurology. 60:702-705.

51. Cannella, B., Cross, A.H., and Raine, C.S. 1990. Upregulation and coexpression of adhesion molecules correlate with relapsing autoimmune demyelination in the central nervous system. J. Exp. Med. 172:1521-1524.

52. Ensoli, F., et al. 2002. Lymphomononuclear cells from multiple sclerosis patients spontaneously produce high levels of oncostatin $M$, tumor necrosis factors alpha and beta and interferon gamma. Mult. Scler. 8:284-288.

53. Nagano, I., et al. 1994. Expression of cytokines in brain lesions in subacute sclerosing panencephalitis. Neurology. 44:710-715.

54. Rieckmann, P., et al. 1994. Cytokine mRNA levels in mononuclear blood cells from patients with multiple sclerosis. Neurology. 44:1523-1526.

55. Korner, H., et al. 1997. Tumor necrosis factor blockade in actively induced experimental autoimmune encephalomyelitis prevents clinical disease despite activated $\mathrm{T}$ cell infiltration to the central nervous system. Eur. J. Immunol. 27:1973-1981. 